\title{
顎下部に発生した異所性甲状腺例
}

$\begin{array}{lrrr}\text { 鈴木 } & \text { 政博・多田 } & \text { 靖宏・松塚 } & \text { 崇 } \\ \text { 小川 } & \text { 洋・鹿野 } & \text { 真人・大谷 } & \text { 巌 }\end{array}$

\section{A Case of Ectopic Thyroid in the Left Submandibular Region}

\author{
Masahiro Suzuki, Yasuhiro Tada, Takashi Matsuzuka, Hiroshi Ogawa, \\ Makoto Kano and Iwao Otani \\ (Fukushima Medical College)
}

\begin{abstract}
We report a case of a 46-year-old female with an ectopic thyroid located in the left submandibular region. The pre-operative thyroid function showed normal values. First, Tc $99 \mathrm{~m}$ scintigraphy confirmed the presence of a normally placed thyroid, and the ectopic thyroid could not be distinguished from a salivary gland tumor.

It was not surgically excised because a histological examination of the open biopsy revealed that the tumor consisted of normal thyroid tissue. The post-operative thyroid function showed normal values. In reviewing the literature, we found three cases in which the surgical removal of an ectopic submandibular thyroid led to hypothyroidism. Post-operative $\mathrm{I}^{123}$ scintigraphy disclosed a nodular uptake in the left submandibular region. The ectopic thyroid showed normal functioning by the immuno-histologic examination of anti-thyroglobin antibody.
\end{abstract}

Key words : ectopic thyroid, submandibular region, normally functioning

\section{はじめに}

異所性甲状腺は甲状腺原基の下降障害により生ずる発 生学的位置異常が大部分を占め, 舌部, 舌根部, 舌下部, 甲状軟骨前方などの正中部に発生することが多い.今回 われわれは左顎下部に異所性甲状腺が存在したきわめて まれな 1 症例を経験したので若干の文献的考察を加えて 報告する。

\section{症例}

患者 : 46歳, 女性.

主訴 : 左顎下部の腫瘤.

既往歷 : 17歳時より甲状腺機能立進症があり21歳時と 36 歳時の 2 度にわたり外科で甲状腺亜全摘術を施行され た.

現病歷 : 平成 8 年頃 $(43$ 歳時) から左䫟下部の腫瘤に気
付いていたが放置していた．平成10年 8 月頃から腫瘤の 増大傾向を自覚したため, 通院中の外科で超音波検査を 施行された．超音波検査上，左顎下部に低信号の陰影が 認められ，平成10年 9 月 22 日に精査目的に当科に紹介と なった。同日外科で施行した甲状腺機能検查の結果は, $\mathrm{T}_{3} 2.1 \mathrm{ng} / \mathrm{ml}$ (正常範囲 ; $0.8 \sim 1.6 \mathrm{ng} / \mathrm{ml}$ ), $\mathrm{FT}_{4} 1.4$ $\mathrm{ng} / \mathrm{dl}(0.7 \sim 2.0 \mathrm{ng} / \mathrm{dl})$, TSH $1.4 \mu \mathrm{U} / \mathrm{ml}(0.5 \sim 3.0 \mu \mathrm{U}$ $/ \mathrm{ml})$ とほぼ正常範囲内であった。頸部の単純 CT では, 周囲に比べてやや高信号の陰影を認め, 造影 CT では造 影効果のある境界明瞭な腫瘤陰影を認めた（図 1 ). MRI では T1 強調画像で低信号, T2 強調画像で高信号, ガドリニウム造影による $\mathrm{T} 1$ 強調画像では造影効果のあ る高信号の境界明瞭な陰影を示した（図 2 ). 術前のテク ネシウムシンチでは左顎下部に高濃度の集積を認めたが (図 3 ), ガリウムシンチでは同部位の集積は認められな 


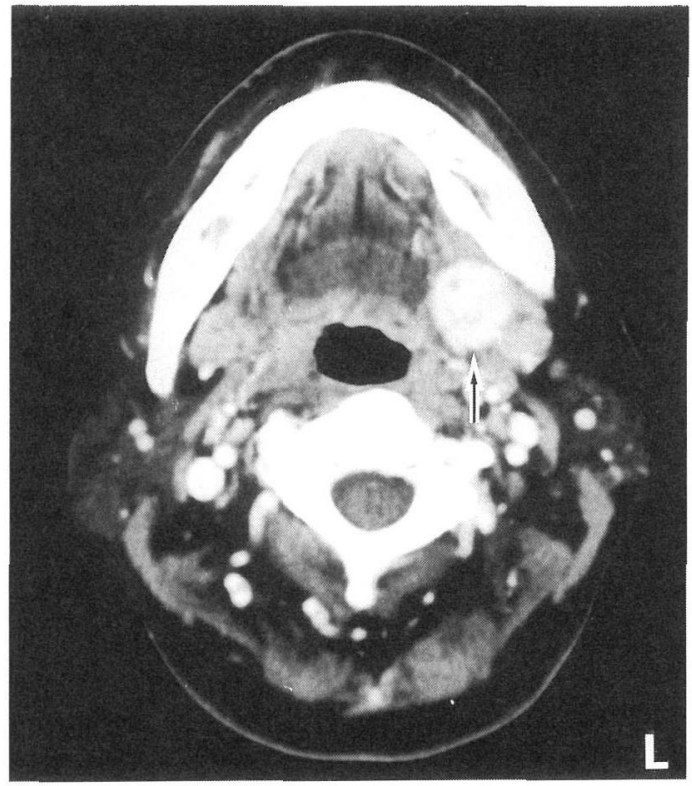

図 1 造影 CT

左顎下部に境界明瞭で造影効果のある腫瘤陰影( 个)を認 める.

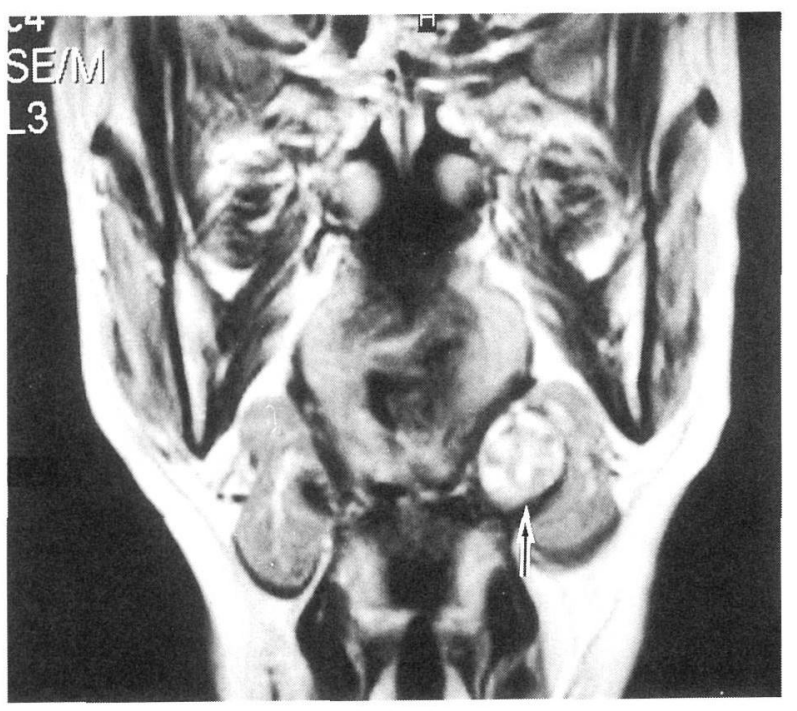

図 2 MRI (ガドリニウム造影)

左顎下部深部にほぼ均一に造影効果のある境界明瞭な腫 瘤陰影 $(\uparrow)$ を認める.

からた. 以上の検査結果から顎下部腫瘍が疑われ平成 11 年 2 月 17 日当科入院となった。入院時, 左顎下部に双手 診にて，20×20 mm の表面平滑で弾性硬，可動性やや 不良な腫瘤を触知した。血液生化学検査では特に異常は

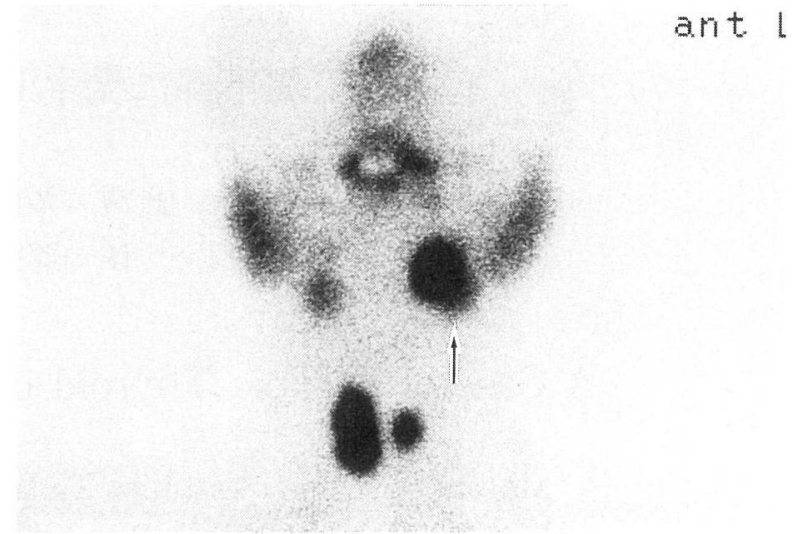

図 3 テクネシウムシンチ

左顎下部に高度の集積 $(\uparrow)$ 艺認める。

認めず，甲状腺機能は $\mathrm{FT}_{4} 1.1 \mathrm{ng} / \mathrm{dl}, \mathrm{TSH} 0.62 \mu \mathrm{U} / \mathrm{ml}$ と正常範囲内であった。2月22日に全身麻酔下に腫瘍摘 出術を予定した。摘出に先立ち，開放生検術を施行した。 術中所見では腫瘤は被膜を有し，顎下腺との連続は認め ず顎二腹筋後腹の深部に存在していた．被膜内の組織は 血管性に富み暗赤色を示していた（図４），腫瘤の一部を 楔状に切除し術中迅速組織検査を行ったところ, 異型の ない立方上皮からなる濾胞構造を認める正常甲状腺組織 との診断であった(図 5 )。術中の病理組織学的所見から 腫瘤以異所性甲状腺と考㝋られたため, 腫瘤を摘出せず そのまま閉創した。術後の甲状腺機能は $\mathrm{FT}_{4} 1.4 \mathrm{ng} / \mathrm{dl}$,

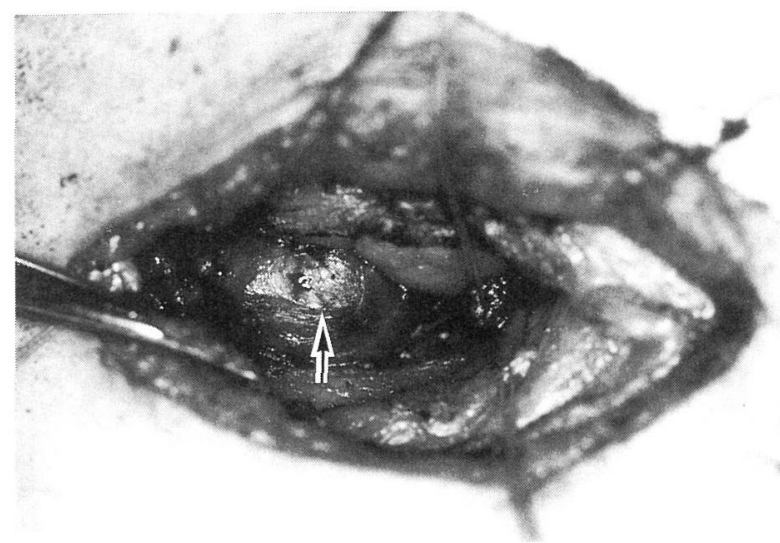

図 4 術中所見

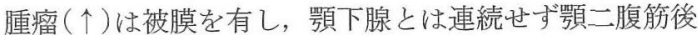
腹の深部に存在し，被膜内の組織は血管性に富及暗赤色 を示していた。 


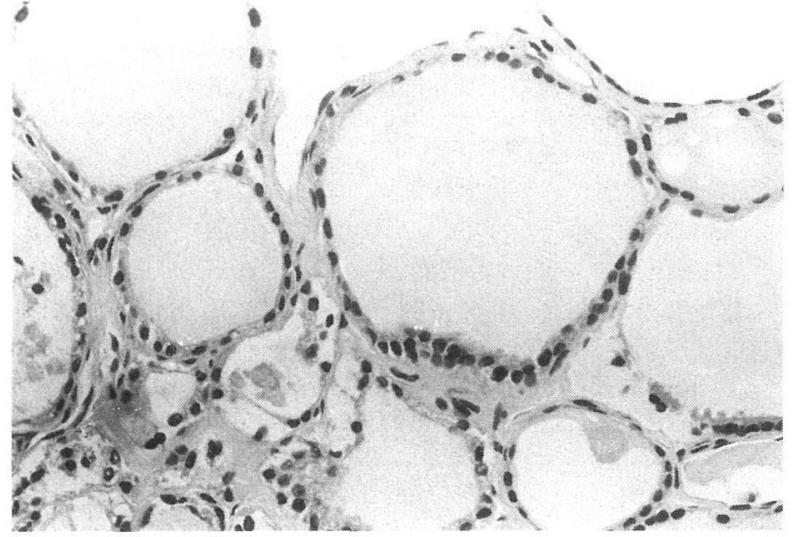

図 5 病理組織所見 $(\mathrm{HE}$ 染色 $\times 100)$

異型のない立万上皮からなる濾胞構造を認める甲状腺組 織.

A

ant $L$
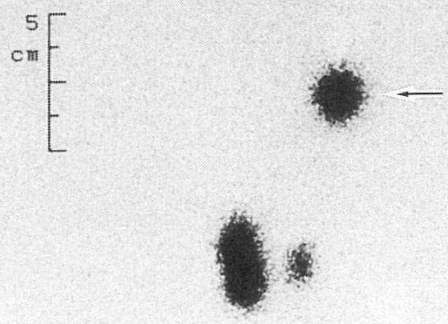

(

B

\section{I-123 UPTAKE $52.2 \% / 5 H R$}

図 6 I 123 シンチ

（A）今回生検後の $I^{123}$ シンチ. 左嵿下部に正常位置の 甲状腺と同程度の高度の集積を認める(

(B) 36歳時 ( 2 度目) に施行された甲状腺亜全摘術前の I 123 シンチ。左頸下部にわずかに集積を認める $(\uparrow)$.
TSH $0.24 \mu \mathrm{U} / \mathrm{ml}$ と異常を認めず 3 月 10 日に退院した. 術後施行したI 123 シンチに和いて左罘下部に正常位置の 甲状腺と同程度の集積を認めて特りこれら甲状腺組織の uptake は9.4\%/5h と正常下限程度であった。これらの 結果から再度以前に施行されたI 123 ンンチの結果を検討 してみると，36歳時に外科での 2 度目の甲状腺巠全摘術 を施行される前に行った $I^{123}$ シンチに拈いても同部位に わずかではあるが集積を認めていた(図6).

\section{考察}

異所性甲状腺は女性に多く発生し, 腫瘤性病変として 発症するが，その時期としては思春期，青壮年期，妊娠 中が多く, この時期に甲状腺ホルモンの需要が増大し異 所性甲状腺が刺激されて，腫大するためと考光られてい る1). その発生原因には主に甲状腺原基の下降障害によ るものと迷入によるものとがある、下降障害の場合, 舌 根部に発生するものが大部分を占め, その活とんどが正 中部に発生し, この約70\%の例では異所性甲状腺が唯一 の甲状腺であると報告されている2．一方，迷入による ものでは正常位置の甲状腺のほかに, 喉頭内, 気管内, 上部食道内, 頸部リンパ節内への存在が報告されてい る3゙。なた臨床症状としては, 舌根部発生によるもので は腫瘤による咽頭異物感, 苝下障害と甲状腺機能低下が

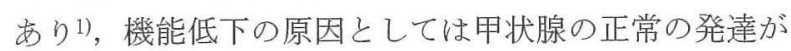
妨げられることによると考光られている4). 一方, 迷入 によるものでは単に腫瘤として触れることが多く, 他の 臨床症状を伴わないことが迷入による異所性甲状腺の診 断を困難にしている. 本症例では正常位置に甲状腺を有 しさらに左顎下部に異所性甲状腺が存在して括り, 甲状 腺原基の一部が分離して迷入した症例であると考兄られ た、診断には種々の検査があるが，I I 123 シンチグラムが 最も有用であり, 本来の甲状腺組織の有無や異所性甲状 腺の存在も診断することができるとされている11. 本症 例では正中を外れた迷入による異所性甲状腺が存在して いたが，腫瘤の穿刺吸引細胞診は周辺組織の損傷を伴う 危険があったため, あ光て施行しなかった。触診, 術前 の甲状腺機能検查, 画像所見からのみでは顎下部の腫瘍 性疾患との鑑別が非常に困難であったが，テクネシウム シンチで高度の集積があり唾液腺腫瘍, 異所性甲状腺の 可能性が市り，開放生検を行いその組織診断基づいて 治療法を選択することとした。本例のように䫁下部に異 所性甲状腺が存在していた例はわれわれが渉猟した限り 
表 1 顎下部異所性甲状腺の報告

\begin{tabular}{|c|c|c|c|c|c|}
\hline 報 告 者 & 年・性 & 術前甲状腺機能 & 顎下部操作 & 他の甲状腺の部位 & 術後機能 \\
\hline Helidonis 5 ${ }^{5)}(1980)$ & $30 \cdot$ 女 & & 摘出 & オトガイ下 & 低下 \\
\hline Alsop 56) (1986) & 61 ·男 & & 摘出 & 舌骨後部 & 低下 \\
\hline Aguirre 57) (1991) & 47 ·女 & & 部分切除 & $(-)$ & 正常 \\
\hline Morgan 58) (1995) & $50 \cdot$ 女 & & 摘出 & 舌根部 & 低下 \\
\hline Sironi $5^{9)}(1996)$ & $34 \cdot$ 女 & 正常 & 細胞診のみ & 正常位置 & 正常 \\
\hline Ignasi $~^{10)}$ (1996) & $45 \cdot$ 女 & 正常 & & $(-)$ & \\
\hline Aköz ら ${ }^{11)}$ (1998) & 55 ・男 & & 摘出 & 正常位置 & 正常 \\
\hline Temmel $5^{12)}$ & $18 \cdot$ 女 & 低下 & & $(-)$ & \\
\hline 自験例 & $46 \cdot$ 女 & 正常 & 開放生検 & 正常位置 & 正常 \\
\hline
\end{tabular}

では本邦では報告がなく，海外では８例報告されている そすぎない、） 12（表 1）。そのうち本例のように顎下部 以外の部位にも甲状腺が存在している報告は 5 例(5)68)(9)11) あり，4 例5668)111 で㴿下部の異所性甲状腺が摘出されて いる.このらち 3 例5)68) は術後機能低下を認めたとの報 告があり, 頸下部の甲状腺組織が機能を有していたこと を示唆するものであった。 また，2 例911)では本症例と 同様に正常位置にも甲状腺を有していた。 このらち Aköz ら11)の症例では顗下部の甲状腺組織が摘出されて特り, この症例では術後機能低下を示していないが, 摘出され た組織は哄胞状の部分を多く含んで抢り, ぞの程度の機 能性を有していたかは不明である。をた, Ignasi ら ${ }^{10)}$ の症例では顎下部の異所性甲状腺が甲状腺癌の転移によ るものであることを除外するために摘出を勧めたが本人 が希望せず，超音波下での穿刺吸引細胞診のみが行われ た. 結果は異型細胞を認めない滤胞細胞であった. 本症 例は術前甲状腺機能が正常であり手術時の開放生検で正 常甲状腺組織であることが確認されたため摘出術を施行 しなかった. 術後の甲状腺機能の低下は認められず正常 範囲内であった。開放生検による病理組織学的所見と術 後の $I^{123}$ シンチで左顎下部に高度の集積を示したことか ら，本例の異所性甲状腺は十分に機能を有していると考 兄られた。 その機能性ついて検討するために，われわれ は 2 度目 (36歳時) の甲状腺亜全摘術時の標本之, 今回顎 下部生検時の甲状腺組織に対して, 抗サイログロブリン 抗体による免疫組織染色を施行した(図 7 )。前者ではコ ロイド内に立方上皮細胞に接して空胞化を認めコロイド 吸收像を示して和り，立方上皮細胞は一部円柱状で重層 化を示し, 甲状腺機能進症に和いてみられる所見を示 していた，後者ではコロイド内が陽性を示し, 立方上皮

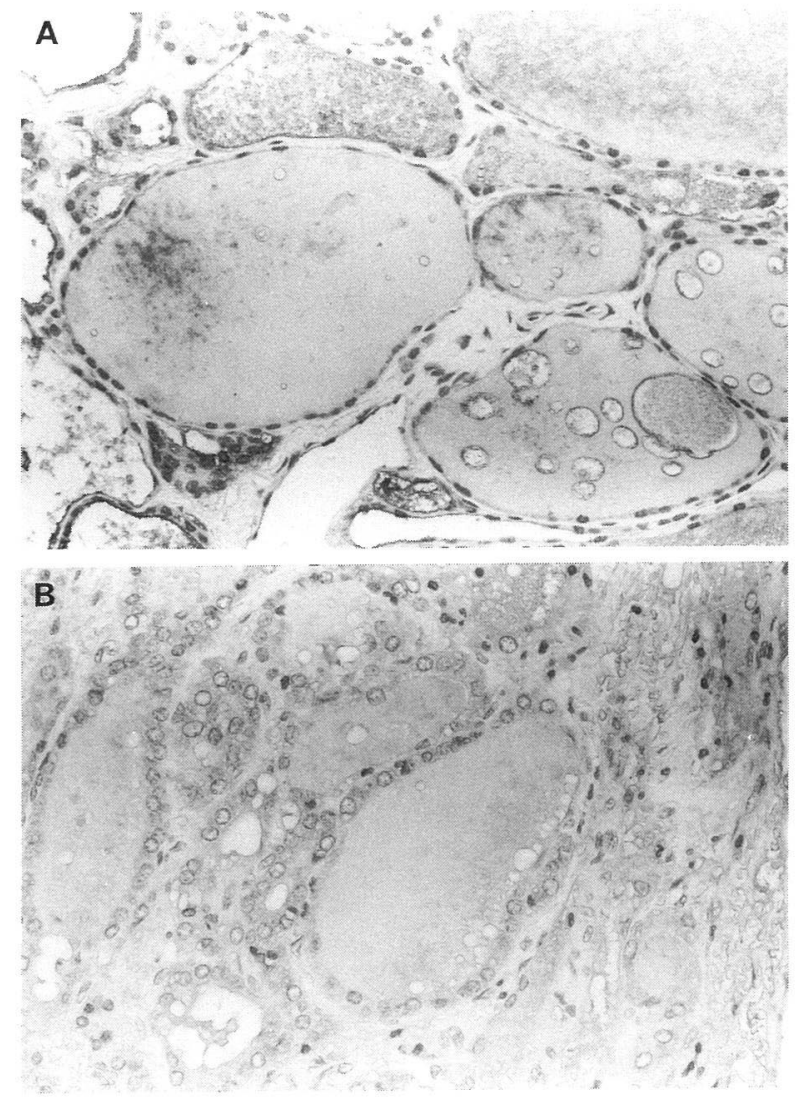

図 7 抗サイログロブリン抗体染色による免疫組織学的所見

(A) 今回生検後. コロイド内は染色され立方上皮細胞 は扁平化して特り正常の甲状腺組織でみられる所 見を示していた. $(\times 100)$

(B) 36 歳時 ( 2 度目) 飞施行された甲状腺亜全摘術前. コロイド内に立方上皮細に接して空胞化を認めコ ロイド吸收像を示していた，また，立方上皮細胞 は一部円柱状で重層化を示していた。 $(\times 100)$ 
細胞は扁平化して括り正常の甲状腺組織であった。これ らのことは，罘下部の異所性甲状腺が機能を有している ことまた，正常位置と買下部の甲状腺組織が異なるも のであることを示唆する貴重な所見であった。

$$
\text { まとめ }
$$

左顎下部に発生したきわめてまれな異所生甲状腺の 1 症例について報告した．本症例では正中を外れて異所性 甲状腺が存在し, 正常位置にも甲状腺が存在していた。 䫇下部甲状腺の発生原因は迷入々考兄られた. 免疫染色 より䅡下部の甲状腺組織は甲状腺機能を有していると考 えられた。

本論文の要旨は第61回耳鼻咽喉科臨床学会(1999年 6 月 25 , 26日別府市)に於いてロ演した。

\section{参考文献}

1 ) 川合優子, 小出千秋, 今井昭雄, 他: 異所性甲状腺の 2 症 例. 新潟市病医誌 $18: 47 \sim 50,1997$.

2) Haddad A, Frenkiel S, Costom B, et al : Management of the undescend thyroid. J Otolaryngol $15: 373 \sim 376$, 1986.

3 ) Okestad S, Mair I, Sundsfjord J, et al : Ectopic thyroid tissue in the head and neck. J Otolaryngol $15: 52 \sim 55$, 1986.

4 ) 浅井 寿, 富田 博, 上条隆司, 他 : 前頸部腫瘤を呈した 異所性甲状腺の 2 例. 小児臨床 $45: 2469 \sim 2472,1992$.

5 ) Helidonis E, Dokianakis G, Papazoglou G, et al : Ectopic thyroid gland in the submadibular region. J Laryngol Otol $94: 219 \sim 224,1980$.

6 ) Alsop JE, Yerbury PJ, O'Donnel PJ, et al : Signet-ring cell microfollicular adenoma arising in a nodular ectopic thyroid; a case report. J Oral Pathol $15: 518 \sim 519$, 1986.

7 ) Aguirre A, de la Piedra M, Ruiz M, et al : Ectopic thyroid tissue in the submandibular region. Oral Surg Oral Med Oral Pathol $71: 73 \sim 76,1991$.

8 ) Morgan NJ, Emberton P and Barton RP : The importance of thyroid scanning in neck lumps; a case report of ectopic tissue in the right submandibular region. J Laryngol Otol $109: 674 \sim 676,1995$.

9 ) Sironi M, Assi A, Andruccioli M, et al : Submandibular ectopic thyroid gland. Clin Nucl Med 21 : 585, 1996.

10) Ignasi Sambola-Cabrer, José-Manuel Fernández-Real, Wifredo Ricart W, et al : Ectopic thyroid tissue presenting as a submandibular mass. Head Neck $18: 87 \sim 90,1996$.

11) $T$ Aköz, B Erdogan, $M$ Ayhan, et al : Ectopic submandibular thyroid tissue. Rev Laryngol Otol Rhinol 119 : 323 325, 1998.

12) Temmel A, Baumgartner W, Steiner E, et al : Ectopic thyroid gland simulating a submandibular tumor. Am J Otolaryngol $19: 342 \sim 344,1998$.

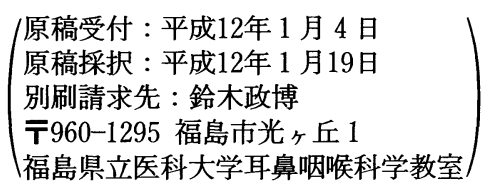

